\title{
INHERITANCE OF RESISTANCE TO WINTER INJURY AND ITS CORRELATION WITH CREEPING ROOTEDNESS IN ALFALFA ${ }^{1}$
}

\author{
D. H. Heinrichs ${ }^{2}$ and F. H. W. Morley ${ }^{3}$ \\ [Received for publication December 7, 1959]
}

\begin{abstract}
An analysis of scores for winter hardiness in a population of plants of alfalfa, derived from Medicago falcata L. x M. media Pers., indicated that most of the genotypic variation was non-additive. The genotypic correlation between winter hardiness and creeping root was found to be 0.38 , increased winter hardiness being associated with increased creeping rootedness.
\end{abstract}

\section{INTRODUCTION}

Although it is a well known fact that cold hardiness differences exist between varieties and lines of alfalfa as well as in other crops [Peltier and Tysdal (8) and Levitt (4)], there appear to be no reported analyses of the genotypic variation within populations under selection. This paper presents an analysis of data from populations of alfalfa, originating from Medicago falcata L. $\mathrm{x}$ Medicago media Pers. crosses, and which formed the basis of the very hardy Canadian variety Rambler [Heinrichs (1) and Heinrichs and Bolton (2)]. The significance of the analysis in relation to breeding programs is briefly discussed.

\section{MATERIALS AND METHODS}

The alfalfa material under consideration is the same as that studied and analysed for the creeping-rooted character by Morley and Heinrichs (7). The plants were scored for winter injury on the basis of three values: 1 . = no injury; $2 .=$ some injury but not death; $3 .=$ death. The data analysed were the mean scores for plots containing from a low of 2 to a high of 13 plants.

The experiment consisted of two replicates each containing row plots. The plants in each plot were all derived from a particular cross and were full sibs. These full sibs were arranged in groups with one parent in common, the relationship between plants within groups being that of half sibs, except where plants were full sibs, as were individuals within a plot. The analysis followed that of Kempthorne (3, Section 20) with a modification suggested by Morley (6), using a model in which all variables are assumed to be random.

\footnotetext{
1Joint contribution from Research Branch, Canada Department of Agriculture, and C.S.I.R.O. Division of Plant Industry, Australia.

2Head, Forage Crops Section, Dominion Experimental Farm, Swift Current, Saskatchewan.

3Geneticist, Division of Plant Industry, Commonwealth Scientific and Industrial Research Organization, Canberra, Australia.
}

TABLE 1.-ANALYSIS OF VARIANCE OF WINTER INJURY PLOT MEANS

\begin{tabular}{l|r|r}
\multicolumn{1}{c|}{ Source of variance } & d.f. & M.S. \\
\hline Replicates & 1 & 0.0000 \\
Common parents & 33 & $0.1106^{*}$ \\
Variable parents in common parents & 121 & $0.0602^{*}$ \\
Common parent x replicate interaction & 33 & $0.0485^{*}$ \\
Residual & 121 & 0.0313 \\
\hline
\end{tabular}

*P. less than 0.05 .

NotE: Common parent and variable parent replace sire and dam respectively in Kempthornes notations (3). 
TABle 2.-Estimates OF COMPONENTS OF VARIANCE AND COVARIANCE

\begin{tabular}{l|c|c|c}
\hline \multicolumn{1}{c|}{ Component } & Creeping root & Winter injury & Covariance \\
\hline Replicate & 0.001 & 0.0000 & 0.000 \\
Cov half sibs (HS) & 0.091 & 0.0037 & 0.016 \\
Cov full sibs (FS) - Cov (HS) & 0.062 & 0.0144 & 0.003 \\
$\sigma$ sr $^{2}$ (common parents x rep. interaction) & 0.004 & 0.0038 & 0.000 \\
Residual & 0.184 & 0.0313 & 0.023 \\
\hline
\end{tabular}

TABle 3.-Modified analysis of Covariance

\begin{tabular}{l|r|r|r|c}
\hline \hline & \multicolumn{4}{|c}{ Mean Squares } \\
\cline { 2 - 4 } & d.f. & Creeping root & Winter injury & Covariance \\
\hline Between replicates & 1 & $\begin{array}{l}0.2000 \\
0.4877^{*} \\
\text { Between crosses }\end{array}$ & $\begin{array}{l}0.0000 \\
0.0710^{*}\end{array}$ & $\begin{array}{l}0.0000 \\
0.0597 \\
\text { Residual }\end{array}$ \\
\hline
\end{tabular}

*P. less than 0.001

\section{RESULTS AND DISCUSSION}

The analysis of variance for cold hardiness is given in Table 1.

From this analysis and the expectations of mean squares as given by Morley and Heinrichs (7), the components of variance were estimated. They are shown in Table 2, along with those for the creeping-rooted character (7). The components of covariance for winter injury $\mathrm{x}$ creeping rootedness were calculated and are presented in the last column of Table 2.

Several correlations may be estimated from these components but obviously sampling errors must be so large for some that the values obtained can have little meaning. Accordingly a simple two-way analysis was made and this is presented in Table 3.

From Table 3 a genotypic correlation may be estimated by subtracting the residual mean square or cross-product from that between crosses. The genotypic correlation then is:

$$
(0.0597-0.0221) / \sqrt{(0.487 \overline{7}}-0.1881)(\overline{0.0 .10-0.0350)}=0.38
$$

This positive correlation indicates that increased cold resistance is associated with increased creeping rootedness.

The most important feature of the variance analysis shown in Table 1 and the components of variance and co-variance in Table 2 is the fact that for winter injury the estimate of $\mathrm{Cov}$ (FS) - Cov (HS) is much larger than that of $\operatorname{Cov}(\mathrm{HS})$. This indicates that considerably less than half the genotypic variance is additive for winter hardiness as compared to being predominantly additive for the creeping-rooted character. Thus, the winter hardiness character cannot be expected to be responsive to mass selection.

Such a result is not wholly surprising, when one considers that natural and artificial selection of winter hardiness must have been especially severe, over many generations, in both parents of the original material [Heinrichs 
(1)]. As a result one might expect most additive genotypic variance to have been fixed. On the other hand, selection for creeping root was of recent origin in the material derived from the Medicago falcata $\mathrm{x}$ M. media crosses and would have been negligible or non-existent in the Ladak parent and probably of relatively low intensity in $M$. falcata, as judged by the heterogeneity evident in that material. Therefore, the finding that genotypic variation for creeping root was entirely additive was to be expected in the light of the suggestions of Sprague and Tatum (9). These authors found that in highly selected material, but not in what they termed unselected material, the variance of general combining ability (the additive portion) was small relative to that of specific combining ability (nonadditive). However, as discussed by Matzinger et al. (5) the situation is not entirely clear.

The interpretation of this result in terms of selection programs is complicated by the fact that the degree of winter hardiness in this material is probably far greater than that necessary in breeding material designated for moderate environments. Under such conditions genotypic variance may well be more predominantly additive. The material under consideration was designated for the development of a creeping-rooted and winterhardy alfalfa for the Canadian prairie, an environment demanding, far more than most, ability to survive extreme cold and drought.

The crucial question is, then, whether or not selection for creeping root is likely to result in a decline in winter hardiness or an increase. The positive genotypic correlation of \pm .38 found in the material under consideration indicates that selection for increased creeping rootedness will probably be accompanied by increased hardiness. However, the positive correlation could possibly obscure an independent or even negative relationship since the characters were "in coupling" in the parental material, and some linkage between polygenes could remain in these early generations and backcrosses. Nevertheless, the small amount of additive genotypic variance for the winter hardiness character reinforces the viewpoint expressed by Morley and Heinrichs (7) that selection programs should include some form of progeny testing along with mass selection.

\section{REFERENCES}

1. Heinrichs, D. H. Developing creeping rooted alfalfa for pasture. Can. J. Agr. Sci. 34:269-280. 1954.

2. Heinrichs, D. H., and J. L. Bolton. Rambler alfalfa. Can. Dept. Agr. Publ. 1030, pp. 5-15. 1958.

3. Kempthorne, $O$. An introduction to genetic statistics. John Wiley \& Sons, New York, N.Y. 1957.

4. Levitt, J. The hardiness of plants. Academic Press, New York, N.Y. 1956.

5. Matzinger, D. F., G. P. Sprague, and C. C. Cockerham. Diallel crosses of maize in experiments repeated over locations and years. Agron. J. 51:346-350. 1959.

6. Morley, F. H. W. An effect of genotypic x environment interactions on estimation of genotypic covariances. (Submitted for publication in Australian J. Statistics).

7. Morley, F. H. W, and D. H. Heinrichs. Breeding for creeping root in alfalfa, Medicago media Pers. Can. J. Plant Sci. 40:424-433. 1960.

8. Peltier, G. L., and H. M. Tysdal. Wilt and cold resistance of self-fertilized lines of alfalfa. Nebraska Agr. Expt. Sta. Rept. 1934.

9. Sprague, G. P., and L. A. Tatum. General vs. specific combining ability in single crosses of corn. J. Amer. Soc. Agron. 34:923-932. 1942. 